\title{
Imaging the Ancients
}

\author{
Rodney H Reznek \\ From International Cancer Imaging Society Meeting and 15th Annual Teaching Course (ICIS 2015) \\ London, UK. 5-7 October 2015
}

Mummified remains and artefacts, since their discovery, have attracted the interest of scientific investigators. Consequently virtually every paleoimaging modality has been applied to bioarchaeology soon after its technological development. Indeed, the first use of X-rays in mummy investigation was only one year after William Röntgen discovered X-rays in 1895 when, in March 1896, Carl Koenig, a German physicist, published the first X-rays involving mummies, that of an Egyptian mummified cat and the knees of an Egyptian child mummy. The first systematic analysis of a major mummy collection was undertaken at the Field Museum in Chicago in 1931. CT scans of mummies were first carried out in 1977. Not surprisingly, over the years, several problems have been identified in interpreting the images on CT. The presence of many layers of mummy wrapping, organ removal, diagenetic changes, particularly desiccation, may all result in confusion. Special problems in X-ray and CT scanning arise when the diagenetic changes are so massive that the remaining tissues, including bone, are severely degraded - a feature best shown by bog bodies, all of which date to the Northern European Iron Age (approximately 500 BC to $500 \mathrm{AD})$.

Recent technological advances have made MDCT an especially useful means for presentation of findings of anthropological inquiry as exemplified in a brilliant recent exhibition at the British Museum. However, this short lecture will show an almost unique personal experience of imaging of mummies performed over almost a decade in the mid-80s and early 90s. Investigations were undertaken of a bog body discovered in Lindow near Manchester, Muisca bodies discovered in the Andes, and Egyptian mummies from Fayum. All three projects revealed fascinating insights into the lifestyle of these ancients and answered several lines of anthropological

Barts Cancer Institute, Barts and The London School of Medicine and Dentistry, Queen Mary University of London, UK inquiry. This presentation will illustrate examples from each of these projects.

Published: 2 October 2015

\section{References}

1. Beckett RG: Paleoimaging: a review of applications and challenges. Forensic Sci Med Pathol 2014, 10(3):423-36.

2. Wade $A D$, et al: Scenes from the past. Multidetector $C T$ of Egyptian mummies of the Redpath Museum. Radiographics 2012, 32:1235-1250.

3. Cox SL: A critical look at mummy CT scanning. Anat Rec 2015, 298(6):1099-1100.

4. Previgliano $\mathrm{CH}$, et al: Radiology evaluation of the Llullaillaco mummies. AJR 2003, 181:1473-1479.

5. Reznek $\mathrm{RH}$, et al: Computed tomography of Lindow Man. In Lindow Man, The Body in the Bog. British Museum Publications;Stead I.M., Bourke, J.G., Brothwell, D. 1985:.

doi:10.1186/1470-7330-15-S1-O21

Cite this article as: Reznek: Imaging the Ancients. Cancer Imaging 2015 15(Suppl 1):O21.

\section{Submit your next manuscript to BioMed Central and take full advantage of: \\ - Convenient online submission \\ - Thorough peer review \\ - No space constraints or color figure charges \\ - Immediate publication on acceptance \\ - Inclusion in PubMed, CAS, Scopus and Google Scholar \\ - Research which is freely available for redistribution \\ Submit your manuscript at www.biomedcentral.com/submit \\ () Biomed Central}

C Biomed Central

(c) 2015 Reznek This is an Open Access article distributed under the terms of the Creative Commons Attribution License (http:// creativecommons.org/licenses/by/4.0), which permits unrestricted use, distribution, and reproduction in any medium, provided the original work is properly cited. The Creative Commons Public Domain Dedication waiver (http://creativecommons.org/publicdomain/ zero/1.0/) applies to the data made available in this article, unless otherwise stated. 